\title{
Providing new products by innovative entrepreneurs in Europe
}

\author{
Jorge Velilla* $•$ Raquel Ortega
}

University of Zaragoza, Spain

Received: 6 August 2019

Revised: 25 November 2019

Accepted: 3 December 2019

\begin{abstract}
This paper addresses the individual factors that determine the provision of new products by entrepreneurs in Europe. To that end, we use the GEM 2014 Adult Population Survey, for sixteen European Countries, focusing on the demographic, economic, and environmental characteristics of this specific group of entrepreneurs. Our results indicate that education, experience, entrepreneurial skills, and income levels are the primary determinants in offering a new product. We also show that, in the case of 'baby' business owners, only the fear of failure and knowing other entrepreneurs are significant factors, while for nascent entrepreneurs, age, education, family size, income, and the social consideration of entrepreneurship also show significant correlations with the probability of offering new products.
\end{abstract}

Keywords: new products; innovation; entrepreneurs; Europe; GEM data

JEL Classification Codes: L26, O3

\section{Introduction}

Entrepreneurship drives social change and is considered to be a strong engine of growth (Minniti, 2008; Galindo and Mendez, 2013). Thus, entrepreneurship is high on the agenda of a number of European politicians and institutions. According to Schumpeter (1934), there is a significant component of entrepreneurial activity that arises from innovation, in the sense of offering new products and technologies, and that is why it is seen as a key driver of socioeconomic development.

Offering new products and technologies has been found to be a key to entrepreneurial success (Baumol, 2002; Acs and Audretsch, 2005), and some authors have analyzed why certain entrepreneurs innovate more, in contrast to those who merely imitate (Baumol, 2010; Soriano and Huarng, 2013; Lukes, 2013; Love and Roper, 2015). However, the behavior of innovative entrepreneurs is an area that requires further research (Lukes, 2013).

To partially bridge this gap, the main objective of this paper is to addresses the individual factors that determine the behavior of those innovative entrepreneurs, relative to non-innovative entrepreneurs, who specifically offer a product that is new and unfamiliar in Europe. We use the information provided by the Global Entrepreneurship Monitor (GEM) 2014 Adult Population Survey (APS) database for sixteen European Countries (Greece, the Netherlands,

*Corresponding author. E-mail: jvelilla@unizar.es.

Citation: Velilla, J., and Ortega, R. (2020) Providing new products by innovative entrepreneurs in Europe, Economics and Business Letters, 9(2), 90-96.

DOI: 10.17811/ebl.9.2.2020.90-96 
Belgium, France, Hungary, Switzerland, Sweden, Norway, Poland, Germany, Portugal, Luxembourg, Finland, Estonia, Czech Republic, and Slovakia). Thus, the main contribution of the paper is to study the individual features that characterize entrepreneurs who offer new and unfamiliar products to their customers. We also study whether these characteristics depend on the stage of the entrepreneurial process, differentiating between nascent entrepreneurs and owners and managers of new businesses.

\section{Data}

We use the GEM 2014 APS data, which contains information for the year 2013, to analyze entrepreneurial activity measured through the contribution to the TEA index. The GEM is "the world's foremost study of entrepreneurship", and provides quality reports and data to promote the study and understanding of entrepreneurial activity. The APS database contains harmonized cross-sectional micro-data on the entrepreneurial characteristics of individuals worldwide. More information about GEM databases can be found at http://www.gemconsortium.org/data /sets.

Our sample is composed of entrepreneurs in sixteen European countries (Greece, the Netherlands, Belgium, France, Hungary, Switzerland, Sweden, Norway, Poland, Germany, Portugal, Luxembourg, Finland, Estonia, Czech Republic, and Slovakia), with entrepreneurs being defined as those who contribute to the Total early-stage Entrepreneurial Activity (TEA) index, whixh assesses the percentage of working-age individuals who are about to start an entrepreneurial activity, or have started one within the last 42 months. ${ }^{1}$

The dependent variable is that of identifying innovative entrepreneurs. The GEM APS data allows us to differentiate between those entrepreneurs who offer new products or services (selfreported), and those who do not. ${ }^{2}$ Among the 2,923 entrepreneurs in our sample, 1,388 of them report being innovators (providing new products), which is $47.49 \%$ of the total.

We include in our analysis a range of independent variables, including sociodemographic factors: age, measured in years; age squared (age $\left.{ }^{2} / 100\right)$; gender; and education (basic, secondary, and University education, in terms of the highest level achieved). Prior research has shown how these variables can have an impact on entrepreneurial activity, so they may also be correlated with innovation among entrepreneurs (Minniti, 2010; Coduras et al., 2018). We also control for the number of children and the family size, labor experience (measured in years), the labor force status (employee, self-employed, student, and unemployed and retiree), and income levels (Castaño et al., 2015). ${ }^{3}$ Innovative businesses that pursue success require high levels of self-confidence, stress tolerance, and individual leadership, intuition, and skills (Stuetzer et al., 2012; Saiz-Alvarez et al., 2013). Therefore, we also include entrepreneurs' selfreported perception of skills and fear of failure. The process of developing or providing a new product or service is dependent on a community of people to bounce ideas off, and get feedback from (Klyver et al., 2012). Thus, the role of peer effects, defined in terms of whether individuals have known other entrepreneurs, may increase the probability of offering new products. Finally, we also control for the appreciation of the entrepreneurial environment, social norms, and media support, as psychological variables that may influence entrepreneurial readiness (Coduras et al., 2016b). Table 1 shows summary statistics of the variables for innovative and non-innovative entrepreneurs.

\footnotetext{
${ }^{1}$ The GEM also defines nascent entrepreneurs as entrepreneurs who are starting a business, and have done so for a maximum of 12 months; and baby business owners as individuals who have begun an enterprise more than 12 months ago, for a maximum of 42 months.

${ }^{2}$ This definition of innovation is self-reported and, thus, may be biased. Specifically, it does not identify individuals who "create" new products. For these reasons, the measurement of "innovation" in GEM APS data is controversial (see Marcotte, 2013).

${ }^{3}$ The APS data defines three dummies, low, middle, and high income.
} 
Table 1. Summary statistics.

\begin{tabular}{|c|c|c|c|c|}
\hline \multirow[t]{2}{*}{ Variables } & \multicolumn{2}{|c|}{ Innovators } & \multicolumn{2}{|c|}{ Non-innovators } \\
\hline & Mean & S.Dev. & Mean & S.Dev. \\
\hline Being male & 0.629 & 0.483 & 0.631 & 0.483 \\
\hline Age & 38.615 & 11.835 & 39.908 & 11.786 \\
\hline Basic education & 0.071 & 0.256 & 0.087 & 0.281 \\
\hline Secondary education & 0.533 & 0.499 & 0.584 & 0.493 \\
\hline University education & 0.396 & 0.489 & 0.329 & 0.470 \\
\hline Experience & 2.336 & 5.894 & 2.007 & 5.459 \\
\hline \multicolumn{5}{|l|}{ Consider to have entrep. } \\
\hline Fear of failure & 0.277 & 0.448 & 0.285 & 0.452 \\
\hline Family size & 3.047 & 1.526 & 3.104 & 1.447 \\
\hline Number of children & 1.614 & 1.495 & 1.550 & 1.410 \\
\hline \multicolumn{4}{|l|}{ Being retired or } & 0.279 \\
\hline Being an employee & 0.467 & 0.499 & 0.457 & 0.498 \\
\hline Being self-employed & 0.414 & 0.493 & 0.442 & 0.497 \\
\hline Being a student & 0.024 & 0.152 & 0.016 & 0.127 \\
\hline Low income & 0.174 & 0.379 & 0.158 & 0.365 \\
\hline Middle income & 0.468 & 0.499 & 0.498 & 0.500 \\
\hline High income & 0.359 & 0.480 & 0.345 & 0.475 \\
\hline $\begin{array}{l}\text { Know someone with entr. } \\
\text { exp. }\end{array}$ & 0.660 & 0.474 & 0.621 & 0.485 \\
\hline $\begin{array}{l}\text { Good consideration of } \\
\text { entrep. }\end{array}$ & 0.385 & 0.487 & 0.376 & 0.485 \\
\hline $\begin{array}{l}\text { Consideration of Media } \\
\text { support for entrep. }\end{array}$ & 0.362 & 0.481 & 0.365 & 0.482 \\
\hline Number of observations & & & & \\
\hline
\end{tabular}

\section{Empirical analysis}

We estimate logistic regressions on the probability to innovate. For a given entrepreneur ' $i$ ', let $p_{i}$ be the probability of offering a new product. $\mathbf{X}_{i}$ is a vector of explanatory variables. We then estimate:

$$
\log \left(\frac{p_{i}}{1-p_{i}}\right)=\beta_{0}+\beta_{1} X_{i}+\varepsilon_{i}
$$

We include $\varepsilon_{i}$ as robust standard errors to control the presence of heteroskedasticity, and also country fixed effects. ${ }^{4}$

Table 2 shows general estimates of Eq. 1 in Column (1). Results indicate that gender and age are not significantly correlated with innovation among entrepreneurs. University education is significantly correlated with innovation, suggesting that Univerity education (but not secondary, compaed to basic education) provides entrepreneurs with the required technical skills to be able to offer new products. Experience is also positively correlated with innovations, along with a good self-evaluation of managerial skills. Among the rest of the regressors, only income levels show a significant correlation with innovation. Specifically, low- and highincome individuals show a higher probability to become entrepreneurs than their middleincome counterparts. It is important to note that several variables included in the analysis, which

\footnotetext{
${ }^{4}$ In addition to the robust standard errors, we have replicated the analysis with country-clustered standard errors, with results that do not meaningfully vary. Estimates are available upon request.
} 
are traditional determinants of entrepreneurship, are not significant when studying innovative entrepreneurs. $^{5}$

Table 2. Logit model estimates.

\begin{tabular}{|c|c|c|c|c|}
\hline VARIABLES & $\begin{array}{c}(1) \\
\text { General }\end{array}$ & $\begin{array}{c}(2) \\
\text { Reduced } \\
\text { sample }\end{array}$ & $\begin{array}{c}\text { (3) } \\
\text { Nascent } \\
\text { entrep. }\end{array}$ & $\begin{array}{c}\text { (4) } \\
\text { Baby } \\
\text { business } \\
\text { owners }\end{array}$ \\
\hline Being male & $\begin{array}{l}-0.023 \\
(0.080)\end{array}$ & $\begin{array}{l}-0.017 \\
(0.084)\end{array}$ & $\begin{array}{c}0.091 \\
(0.117)\end{array}$ & $\begin{array}{c}0.125 \\
(0.149)\end{array}$ \\
\hline Age & $\begin{array}{l}-0.021 \\
(0.021)\end{array}$ & $\begin{array}{l}-0.020 \\
(0.023)\end{array}$ & $\begin{array}{c}-0.047^{*} \\
(0.025)\end{array}$ & $\begin{array}{c}0.004 \\
(0.035)\end{array}$ \\
\hline Age squared & $\begin{array}{c}0.016 \\
(0.025)\end{array}$ & $\begin{array}{c}0.015 \\
(0.028)\end{array}$ & $\begin{array}{c}0.048 \\
(0.030)\end{array}$ & $\begin{array}{l}-0.013 \\
(0.041)\end{array}$ \\
\hline Secondary education & $\begin{array}{c}0.477 \\
(0.295)\end{array}$ & $\begin{array}{l}0.578^{*} \\
(0.345)\end{array}$ & $\begin{array}{c}-0.453 * * \\
(0.201)\end{array}$ & $\begin{array}{c}0.097 \\
(0.238)\end{array}$ \\
\hline University education & $\begin{array}{c}0.734 * * \\
(0.299)\end{array}$ & $\begin{array}{c}0.827 * * \\
(0.349)\end{array}$ & $\begin{array}{l}-0.086 \\
(0.193)\end{array}$ & $\begin{array}{c}0.165 \\
(0.233)\end{array}$ \\
\hline Experience & $\begin{array}{c}0.017 * * \\
(0.007)\end{array}$ & $\begin{array}{c}0.019 * * \\
(0.008)\end{array}$ & $\begin{array}{l}-0.000 \\
(0.010)\end{array}$ & $\begin{array}{c}0.009 \\
(0.014)\end{array}$ \\
\hline Entrepreneurial skills & $\begin{array}{l}0.200^{*} \\
(0.105)\end{array}$ & $\begin{array}{l}0.217^{*} \\
(0.111)\end{array}$ & $\begin{array}{c}0.078 \\
(0.124)\end{array}$ & $\begin{array}{c}0.005 \\
(0.185)\end{array}$ \\
\hline Fear of failure & $\begin{array}{l}-0.055 \\
(0.090)\end{array}$ & $\begin{array}{l}-0.042 \\
(0.095)\end{array}$ & $\begin{array}{l}-0.173 \\
(0.115)\end{array}$ & $\begin{array}{c}-0.341 * * \\
(0.156)\end{array}$ \\
\hline Family Size & $\begin{array}{l}-0.049 \\
(0.033)\end{array}$ & $\begin{array}{l}-0.047 \\
(0.035)\end{array}$ & $\begin{array}{c}-0.072 * \\
(0.037)\end{array}$ & $\begin{array}{l}-0.055 \\
(0.049)\end{array}$ \\
\hline Number of children & $\begin{array}{c}0.025 \\
(0.039)\end{array}$ & $\begin{array}{c}0.027 \\
(0.041)\end{array}$ & $\begin{array}{c}0.045 \\
(0.047)\end{array}$ & $\begin{array}{c}0.028 \\
(0.058)\end{array}$ \\
\hline Being an employee & $\begin{array}{l}-0.120 \\
(0.149)\end{array}$ & $\begin{array}{l}-0.312 \\
(0.287)\end{array}$ & $\begin{array}{l}-0.045 \\
(0.145)\end{array}$ & $\begin{array}{c}0.138 \\
(0.231)\end{array}$ \\
\hline Being self-employed & $\begin{array}{l}-0.180 \\
(0.146)\end{array}$ & $\begin{array}{l}-0.367 \\
(0.287)\end{array}$ & $\begin{array}{l}-0.081 \\
(0.154)\end{array}$ & $\begin{array}{c}0.016 \\
(0.225)\end{array}$ \\
\hline Being a student & $\begin{array}{c}0.192 \\
(0.307)\end{array}$ & - & $\begin{array}{c}0.436 \\
(0.382)\end{array}$ & $\begin{array}{c}0.699 \\
(0.540)\end{array}$ \\
\hline Middle income & $\begin{array}{l}-0.215^{*} \\
(0.116)\end{array}$ & $\begin{array}{c}-0.249 * * \\
(0.124)\end{array}$ & $\begin{array}{c}0.187 \\
(0.145)\end{array}$ & $\begin{array}{c}0.187 \\
(0.201)\end{array}$ \\
\hline High income & $\begin{array}{l}-0.179 \\
(0.125)\end{array}$ & $\begin{array}{l}-0.216 \\
(0.132)\end{array}$ & $\begin{array}{c}0.365 * * \\
(0.162)\end{array}$ & $\begin{array}{c}0.091 \\
(0.217)\end{array}$ \\
\hline Peer effects & $\begin{array}{c}0.103 \\
(0.083)\end{array}$ & $\begin{array}{c}0.106 \\
(0.088)\end{array}$ & $\begin{array}{c}0.236 * * \\
(0.112)\end{array}$ & $\begin{array}{c}0.338 * * \\
(0.159)\end{array}$ \\
\hline $\begin{array}{l}\text { Good consideration } \quad \text { of } \\
\text { entrep. }\end{array}$ & $\begin{array}{l}0.080 \\
(0.090)\end{array}$ & $\begin{array}{c}0.084 \\
(0.095)\end{array}$ & $\begin{array}{c}0.224 * * \\
(0.097)\end{array}$ & $\begin{array}{c}0.158 \\
(0.132)\end{array}$ \\
\hline Media support of entrep. & $\begin{array}{c}0.017 \\
(0.088)\end{array}$ & $\begin{array}{l}-0.018 \\
(0.092)\end{array}$ & $\begin{array}{l}-0.087 \\
(0.096)\end{array}$ & $\begin{array}{l}-0.120 \\
(0.125)\end{array}$ \\
\hline $\begin{array}{l}\text { Country F.E. } \\
\text { Constant }\end{array}$ & $\begin{array}{c}\text { Yes } \\
0.133 \\
(0.565)\end{array}$ & $\begin{array}{c}\text { Yes } \\
0.236 \\
(0.640)\end{array}$ & $\begin{array}{c}\text { Yes } \\
1.026 * \\
(0.608)\end{array}$ & $\begin{array}{c}\text { Yes } \\
-1.332 * \\
(0.809)\end{array}$ \\
\hline Observations & 2,923 & 2,661 & 1,453 & 918 \\
\hline
\end{tabular}

Note: the sample (GEM 2014 APS) is restricted to entrepreneurs who reside in Europe. Column (2) is restricted to entrepreneurs who are not retired or disabled. $* * * \mathrm{p}<0.01,{ }^{*} \mathrm{p}<0.05,{ }^{*} \mathrm{p}<0.1$.

\footnotetext{
${ }^{5}$ We have studied whether estimates suffer from a problem of multicollinearity. The average variance inflation factor (VIF) is 1.9, with the variable with the greatest VIFs being lower than 5, a standard cutoff. We have also examined whether estimates suffer from potential endogeneity by estimating a Lewbel (1997) model, where income levels, entrepreneurial skills, fear of failure, peer effects, good consideration of entrepreneurship, and media support of entrepreneurship are considered endogenous. The model is neither underidentified nor overidentified according to postestimation tests, and estimates, which are available upon request, are robust to general estimates.
} 
Column (2) shows analogous estimates of Eq. 1, where the sample is restricted to individuals who are not retired or unemployed. ${ }^{6}$ The main conclusions derived from Column (1) are robust to estimates shown in Column (2), as results do not differ in general terms. The only qualitative difference is that secondary education is now positive and significant at standard levels. That indicates how not only University, but also secondary education (compared to basic or primary education) are important in determining the ability of entrepreneurs to provide new products.

According to the GEM, different attitudes, motivations, and/or aspirations may characterize different phases of entrepreneurship. Consequently, in Columns (3) and (4) the analysis is replicated for nascent entrepreneurs and baby business owners, respectively, to study whether there are differences in the trends that determine innovation, depending on the stage of the entrepreneurial career. In our sample, 1,453 individuals are nascent entrepreneurs, and 918 are baby business owners. ${ }^{7}$ Among nascent entrepreneurs, $51.3 \%$ of them offer a new product or service, while only $40.7 \%$ of baby business owners offer a new product or service to their customers.

For nascent entrepreneurs, we observe a negative and significant coefficient associated with age, indicating that younger nascent entrepreneurs are more likely to offer new products. In terms of formal education, we find that nascent entrepreneurs with secondary education are less likely to offer new products, compared to their basic and University education counterparts. Then, individuals who have only primary education, or those who have gone to University, are more likely to offer new products. High income is positively correlated with innovation, highlighting the important role of family finances, which may act as a "cushion" in entrepreneurial intentions. Finally, peer effects (knowing other entrepreneurs) and the appreciation of the entrepreneurial environment show a positive and significant correlation with offering new products among nascent entrepreneurs, while they were not significant among the general sample.

In the case of baby business owners, on the other hand, only two variables are significant at standard levels: the fear of failure, and peer effects. For instance, baby business owners who report fearing failure show a lower probability of offering new products, while knowing other entrepreneurs is positively correlated with providing new products. It is important to note that this variable is significant when considering nascent entrepreneurs and baby business owners separately, but is not significant when studying them together. This sheds light on the complexity underlying entrepreneurial processes (Coduras et al., 2016).

\section{Conclusions}

This paper examines the factors that determine the offer of new products from entrepreneurs, in sixteen European countries, using the GEM 2014 APS data. Results indicate that entrepreneurs with experience, who have gone to University, have a high self-evaluation of their skills, and do not have a middle-level income, are the most likely to provide new products. Entrepreneurial ties seem to have an impact on the process of innovation for nascent entrepreneurs and business owners, in line with the entrepreneurial network literature (Klyver, 2012). Conversely, age, gender, and household composition do not appear to drive innovation, although they are traditional predictors of entrepreneurship (e.g., Minniti, 2010; Coduras et al., 2018). Similarly, the fear of failure is also non-significant, despite prior research finding it as a means to ambition (Saiz-Alvarez et al., 2013). Therefore, innovation appears to be a complex

\footnotetext{
${ }^{6}$ The reference category for the labor status of individuals is being a student.

${ }^{7}$ Information about the stage of the entrepreneurial activity is provided for 2,371 individuals.
} 
process that is determined by a variety of channels, depending on the stage of entrepreneurship, which is the main conclusion of our analysis.

The analysis has certain limitations. First, the definition of "innovativeness" in GEM data is controversial. Second, results are based on conditional correlations, and no causal inference can be made from estimates.

Entrepreneurial activity has gained in importance in recent years, especially in Europe, as a labor activity that mitigates the effects of the economic crisis. Thus, policy-makers have a tool, in the promotion of entrepreneurship, to encourage innovation and economic growth. However, it is important to carefully orient policy decisions to optimize their efficiency and efficacy (Naudé, 2016). Studies of entrepreneurial activity that follow an individual approach may help institutions to identify those entrepreneurs and entrepreneurial activities that should be given the greatest incentives.

\section{References}

Acs, Z., and Audretsch, D. B. (2005) Entrepreneurship, Innovation, and Technological Change, Foundations and Trends in Entrepreneurship, 1(4), 149-195.

Baumol, W. J. (2002) The Free-Market Innovation Machine: Analyzing the Growth Miracle of Capitalism, Princeton University Press: New Jersey.

Baumol, W. J. (2010) The Microtheory of Innovative Entrepreneurship, Princeton University Press: New Jersey.

Castaño, M. S., Mendez, M .T., and Galindo, M. A. (2015) The effect of social, cultural, and economic factors on entrepreneurship, Journal of Business Research, 68(7), 1496-1500.

Coduras, A., Clemente, J. A., and Ruiz, J. (2016a) A novel application of fuzzy-set qualitative comparative analysis to GEM data, Journal of Business Research, 69(4), 1265-1270.

Coduras, A., Saiz-Alvarez, J. M., and Ruiz, J. (2016b) Measuring readiness for entrepreneurship: An information tool proposal, Journal of Innovation and Knowledge, 1, 99-108.

Coduras, A., Velilla, J., and Ortega, R. (2018) Age of the entrepreneurial decision: Differences among developed, developing, and non-developed countries, Economic and Business Letters, 7(1), 36-46.

Galindo, M. A., and Mendez, M. T. (2013) Innovation, entrepreneurship and economic growth, Management Decision, 51(3), 501-514.

GEM (2018) Global Report 2017/18, Global Entrepreneurship Research Association, Babson College: Massachusets.

Klyver, K., Hunter, E., and Watne, T. (2012) Entrepreneurial ties and innovativeness in the start-up decision, International Journal of Entrepreneurship and Innovation, 13(3), 153-163.

Lewbel, A. (1997) Constructing instruments for regressions with measurement error when no additional data are available, with an application to patents and R\&D, Econometrica, 65(5), 1201-1213.

Lukes, M. (2013) Entrepreneurs as innovators: A multi-country study of entrepreneurs' innovative behaviour, Prague Economic Papers, 22(1), 72-84.

Marcotte, C. (2013) Measuring entrepreneurship at the country level: A review and research agenda, Entrepreneurship and Regional Development, 25(3-4), 174-194.

Minniti, M. (2008) The role of government policy on entrepreneurial activity: productive, unproductive or destrictive?, Entrepreneurship: Theory and Practice, 32(5), 779-790.

Minniti, M. (2010) Female entrepreneurship and economic activity, European Journal of Development Research, 22(3), 294-312.

Saiz-Alvarez, J. M., Cuervo-Arango, C., and Coduras, A. (2013). Entrepreneurial strategy, innovation, and cognitive capabilities: What role for intuitive SMEs?, Journal of Small Business Strategy, 23(2), 29-40. 
Schumpeter, A. (1934) The Theory of Economic Development, Harvard University Press: Cambridge.

Soriano, D. R., and Huarng, K.H. (2013) Innovation and entrepreneurship in knowledge industries, Journal of Business Research, 66(10), 1964-1969.

Stuetzer, M., Goethner, M., and Cantner, U. (2012) Do balanced skills help nascent entrepreneurs to make progress in the venture creation process?, Economics Letters, 117(1), 186-188. 